Birlesik Dünya Arastırma

BD -CENTER

Innovasyon ve Yayıneılık Merkezi
Global Journal of Foreign

Language Teaching

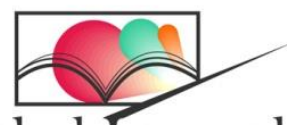

Global Journal

of Foreign Language Teaching

Volume 10, Issue 4 , (2020) 208-223

\title{
EFL students' perception of the role of teaching novels in enhancing writing skills
}

Mutahar Qassem ${ }^{1}$, Najran University, Linguistics and Translation Studies, King Abdulaziz Road, P.O.Box : 1988, Najran, Saudi Arabia https://orcid.org/0000-0001-5951-6042

\section{Suggested Citation:}

Qassem, M (2020). EFL students' perception of the role of teaching novels in enhancing writing skills. Global Journal of Foreign Language Teaching. 10(4), 208-223. https://doi.org/10.18844/gjflt.v10i4.4994

Received from June 12, 2020; revised from September 12, 2020; accepted from November 10, 2020.

Selection and peer review under responsibility of Assoc Prof Dr. Ali Rahimi, Bangkok University,

Thailand.

C2020 Birlesik Dunya Yenilik Arastirma ve Yayincilik Merkezi. All rights reserved.

\section{Astract}

Applied linguists have different viewpoints on the relationship between teaching literature and language. Language through a literature approach theoretically corroborates the role of literature in developing language skills because it exposes students to different styles of writing and authentic materials. Language-structure-based syllabuses might not be sufficient for developing students' language skills. By contrast, an authentic-based syllabus such as novels and short stories motivates language learning and fosters the development of thinking and language skills. In this vein, this study attempts to investigate undergraduates' attitude towards the role of teaching novels in enhancing writing skills, using a survey in which students provided their opinions on the areas that teaching novels helped improve their writing skills. The students' responses were analysed, and a one-sample t-test revealed the students' agreement of the positive role of teaching novels in developing their writing skills at sentence and paragraph levels. Based on these findings, the author recommended the incorporation of novels in the courses of English undergraduate programs, following adequate methods of teaching and selection of appropriate novels that matches' students' linguistic levels.

Keywords: Writing skills, teaching novels, EFL students, perception, enhancement

* ADDRESS FOR CORRESPONDENCE: Mutahar Qassem, Najran University, Linguistics and Translation Studies, King Abdulaziz Road, P.O.Box : 1988, Najran, Saudi Arabia

E-mail address: mutaharnahari@gmail.com 


\section{Introduction}

Integrating literature in English foreign language (EFL) programs remains a controversial issue among applied linguists (İnan \& Yüksel, 2013; Savvidou, 2004; Belcher \& Hirvela, 2000; Lindemann, 1993, Brumfit \& Carter, 1986; McKay \& Petitt, 1984; McKay, 1982). The proponents of integrating literature in EFL programs argue that literature has rich potential to provide authentic materials for language use, whereas the opponents believe that literature complicates the EFL (Belcher, \& Hirvela, 2000; Savvidou, 2004; Gajdusek, 1988; Brumfit \& Carter, 1986).

This study deals with the topic from the students' perspective. The students' perspective of the relationship between teaching novel and writing skills is investigated to see whether the students are for or against the positive relationship between teaching novel and writing skills. Investigating the students' viewpoint is crucial for designers of syllabuses of English undergraduate programs and teachers of English. Furthermore, the students' role is central to learning (Crook and Schmidt, 1991; Tudor, 1993(. Several studies reported a positive relationship between language teaching and literature. However, according to the best of the researchers' knowledge, students' attitudes towards such relations are not investigated, particularly the relationship between writing skills and teaching novels. To bridge this gap, the author used a survey to explore students' attitudes towards the role of novels in enhancing writing skills, based on their studies of 18 novels in the English language program. The research is descriptive because the researcher wants a deep description of the students' attitudes towards the role of the novel teaching in enhancing writing skills.

\subsection{Literature and foreign language learning}

From the 1960s to 1970 s, structuralists theorised that teaching a foreign language is a matter of linguistics, meaning that the focus is only on the correctness of grammatical form, ignoring the content. In the 1980s, applied linguists called for the importance of incorporating literature in English language teaching (Bretz, 1990). They state that literary works should be used in EFL classes to improve communicative competence and providing 'a springboard for the development of critical thinking and aesthetic appreciation' (Bretz, 1990, pp. 335-338). Several conceptual studies show the significance of literature in enhancing students' communicative competence in second language acquisition, namely, Lazar (1993) and Cook (1994).

Using literature in language teaching was hypothesised to have great potentials in enhancing the process of English language learning. Specifically, it attains authentic material, cultural enrichment, language advancement and native -like communicative competence in English (Zacharias \& Manara, 2011; Savvidou, 2004; Obediat; 1997). In the same vein, Helton, Asamani and Thomas (1998) and Oda and Khazall (2009) emphasise the importance of the novel in developing students' language skills, providing rich input on language use.

\subsection{Literature in first and second language writing}

In the early stage of teaching L1 writing, literature was viewed as irrelevant if not a barrier towards teaching composition (Belcher \& Hirvela, 2000). Lindemann (1993) argues that using literature in teaching first language writing is only consuming, not producing texts, indicating that the students did not produce new material when writing about literature and they are merely working on something available. The negative perspective towards the positive effect of literature on first language composition is manifested in Bishop (1995), who has argued that 'literature in the writing classroom tends to overwhelm the study of writing just as the study of literature has traditionally overwhelmed creative writing and composition in English departments" (p. 449). Lately, a change has occurred in the view of scholars towards the effect 
of literature on L1 writing. Hull and Rose (1990) emphasise the role of literary texts in leading students to 'dynamic involvement in generating and questioning knowledge'.

Like the beginning of L1 language composition, L2 compositionists have a negative view towards teaching composition, using literature (Belcher \& Hirvela, 2000). Kelly and Krishnan (1995) and Robson (1989) argue that literary texts are syntactically and lexically difficult. Thus, they cannot assist students to become competent users of the target language. Lately, a change occurred in applied linguists' view towards literature's effect on second language teaching, which was ascribed by Belcher and Hirvela (2000) to the search for teaching materials that would elicit genuine, communicative discourse from language learners because literary texts stimulate responses to interesting plots, characters and themes.

In the 1980s, the 'language through literature' approach emerged. The approach states that students develop their language $r$ through a detailed analysis of literature (Brumfit, 1983; Brumfit \& Carter, 1986.). Krashen (1993) has also seen literature as a valuable tool for language learners. Literary works can be a powerful means of increasing overall language proficiency. The scholars further stated that literature exposes students to narrative forms of discourse and aesthetics (Kramsch, 1993). McKay and Petitt (1984) have explained how literary texts can be used to teach grammar and stimulate the writing of essays. Hirvela and Boyles (1988) studied Hong Kong Chinese students' attitudes towards four genres of literary texts. The students' response revealed that short stories are interesting, useful and enjoyable for them.

Oda and Khaza'll (2009) aimed to find out the extent the novel can play in developing students' language skills and to examine the extent to which the novel may provide them with different vocabulary items and grammatical structures. They found that teaching novels effectively develops students' language skills. They also found that despite the importance of novels in language teaching and learning, it is still not used appropriately and thoroughly due to the procedures and techniques adopted by teachers in teaching novels. Iman (2017) studied the effect of using short stories on improving speaking and writing skills. He found that using short stories significantly improved students' performance in speaking and writing. The author recommended that teachers should integrate literacy instruction in the classroom to develop the EFL learners' performance in speaking and writing, drawing on the potentials of literary works.

As regards studies that deal with students' perspectives in FL literature education, , Liaw (2001) found that students enjoyed integration of literature in a language course. Akyel and Yalçin (1990) found that students' proficiency was attributed to the inclusion of literature in EFL classes. Rietdijk et al. (2017) examined the effects of an innovative comprehensive communicative writing program in upper primary education on students' writing performance and teachers' classroom practices, beliefs and skills. They found the positive effect of the communicative program on students' writing performance and the teachers' use of writing strategies. Bloemert et al. (2019) studied Dutch secondary school students' perspectives on the benefits of their EFL literature education. Students' views revealed that EFL literature component as a means of improving their language skills. Sargsyan and Sivasubramaniam (2013) investigated the use of literature in the Armenian EFL setting whether it can promotes reading and writing skills. Findings revealed literature can significantly contribute to the development of Armenian EFL teaching.

\subsection{Writing skill and the learning process}

Writing is an essential skill not only at the university level but at the primary school level. Students' performance is assessed via writing tasks. Several studies have shown significant effects of writing on learning (Klein and Boscolo, 2016; Atasoy, 2013; Yildiz, 2012). Writing is one of the productive language skills that need special attention due to its need for knowledge, skills and practice. The future of 'writingto-learn' provides many suggestions for studying how writing can become a fruitful tool for elaborating 
and producing knowledge (Klein and Boscolo, 2016). Raimes (1985) demonstrates the importance of writing in learning languages, arguing that writing reinforces the grammatical structures, idioms and vocabulary that are used in teaching. She suggests that writing should not be seen as just one of the language skills to be learned but as an efficient way of generating language. Similarly, Hedge (1988), Harmer (2004) and Klein et al. (2007) believe that writing significantly contributes to learning in general and language learning.

Writing is one of the complex skills that cannot be improved only through a writing course in which students are exposed to the mechanisms of writing. To improve such a skill, the students should be exposed to authentic and natural language and a variety of text types such as descriptive, narrative and argumentative, enabling students to process the language used in such works and reflect this knowledge in their writing either at a sentence or paragraph levels. Intensive reading of narrative texts and students' involvement in writing about such texts may help students improve their writing skills. Rietdijk et al. (2017) found that the effects of an innovative comprehensive writing program in upper primary education on students' writing performance.

\subsection{Writing skills at a sentence level}

Writing a correct, grammatical and meaningful sentence is the basic element of writing skills. This element shows that the students have a good command of the sentence structure, tense and appropriate use of vocabulary. Parts of speech (i.e., nouns, verbs, adjectives, adverbs, pronouns, conjunctions, prepositions) are the basic elements of the sentences. The students need to distinguish between these parts of speech and use them in the right place, which is known as word-order. Conveying meaning is also essential in sentence writing. The students need to know the propositional and referential meaning of the words to deliver the meaning appropriately according to the context. Acquisition of such skills needs knowledge and practice. These areas of language constitute considerable difficulties for the students in the learning situation. Therefore, providing students with the natural input in which they discover these rules may help overcome these difficulties (Krashen, 1998). Effectively using inductive (start by examples and ends with rules) and deductive (start with rules and ends with examples) approaches can assist in teaching such skills (Paesani, 2005). Paesani (2005) emphasised the role of literary texts in language instruction in general and grammar in specific, arguing that 'literary texts serve as the basis of the inductive presentation of new grammatical forms and as a springboard for communicative practice of these forms after explicit instruction' (P.15).

\subsection{Writing skills at a paragraph level}

Linguists and applied linguists agree that writing is a complex task due to the different activities that the writer uses at the same time, including thinking, organising ideas, drafting and editing. Thus, the complexity of writing stems from the fact that the writers need to do many things concurrently with composing. Several studies reported the complexity of writing either in L1 or L2, ascribing such complexity to 'psychological, linguistic, and cognitive reasons' (Mohsen \& Qassem ,2020). The complexity lies in the writer's coordination between planning, drafting and revision (Klein and Boscolo, 2016; McCutchen et al.1994). Therefore, students need to be trained in how to manage between these stages of writing (planning, drafting and revision).

Hedge (1988) presented an integrated vision of the writing process and product. He argued that writing is the result of using various strategies to manage the composing process. Many activities are involved in writing: setting goals, generating ideas, organising information, selecting the appropriate language, making a draft, reading, revision and editing 
The students' reading of novels and writing about the novel (i.e., theme setting, characters, plot) enables students to be engaged in the process of thinking. Furthermore, students are exposed to different types of paragraphs such as narrative and descriptive. By reading novels, students are exposed to the natural input, culture of a native speaker, authentic language, aspects of coherence and logic and aspects of cohesion such as reference and ellipsis. These skills are needed to master written discourse.

The author's review of the literature review revealed the existence of studies on the relationship between teaching literature and English language teaching. However, the students' perspective on such a relationship has not received the attention it deserves, especially between teaching novels and writing skills. Therefore, the present study aims to bridge the gap by investigating students' awareness of the role of teaching novels in enhancing their writing skills. Specifically, the main questions that guided the study are as follows.

1. Do BA students agree about the necessity of teaching novel for improving writing skills?

2. Do the students agree about the relationship between teaching novels and writing skills?

3. Are the bachelor students majoring in English for or against the positive role of teaching novels in enhancing their writing skills at sentence and paragraph levels? In what way do students believe that teaching novels helps develop their writing skills?

\section{Method}

\subsection{Participants}

The subjects of the study were undergraduates in their final year at the Department of English, Ibb University, Yemen. A total of 30 undergraduate students out of 60, 19 men and 11 women with an age range of 22-27, were selected. They started learning English from 7th grade. So that the students can join the Department of English, Ibb University, the students need to take an English Proficiency Test (designed by the department itself). The English language program at Ibb University, Yemen is a literature-oriented program, meaning that literature courses are dominant. Specifically, the students were taught 18 novels from levels 1 to 4 . Thus, the author aimed to explore the students' attitudes towards the effect of teaching novels in developing their writing skills.

\subsection{Questionnaire design}

The questionnaire was designed to consider the objectives of the study. Reflecting on the literature on writing skills, the author classified writing skills into sentence and writing levels and then classified them further into sub-skills (Halliday and Hasan, 2014; Kellogg, 2008; Kroll, 1997). The questionnaire consisted of three Likert scale questions, two questions consisted of two one item and the other two questions consisted of two sections. The first section of the third question had eight items, which dealt with writing skills at the sentence level. The second section dealt with writing skills at the paragraph level, which consisted of thirteen items.

The first question aims to measure the students' view on the necessity of novel teaching for developing writing skills. The second question intends to show students' views regarding the relationship between novel teaching and writing skills. The third question consisted of two sections (i.e., the sentence and paragraph levels). A detailed list of the areas in which teaching novel improves writing skills was provided. The list aimed at eliciting the appropriate answer to the second question of the research project. The first section of the scale has eight items in which the sub-writing skills were listed on a sentence level and the second section has thirteen items on a paragraph level, as seen in the appendix.

\subsection{Data analysis}


The author used a one-sample t-test to analyse the survey of a Likert scale to detect a statistical significance in the distribution of the students' view on the relationship between teaching novels and writing skills. Likert questionnaires are widely used in survey research. Many statisticians propose that ttest can be used to analyse the data collected by the Likert scale questionnaire (de Winter and Dodou, 2010; Harpe, 2015). The survey consists of five points: strongly disagree, disagree, neutral, agree and strongly agree; thus, the t-test can indicate how five-point Likert data look like in a group (de Winter and Dodou, 2010). Accordingly, the author used the t-test to test the sample against a pre-defined (hypothesised value 2, the option of disagreement) to observe the students' distribution of responses around this answer, which is expected to reveal whether the students' responses are directed towards disagreement. These values were represented by the hypothesised value (2), neutralism (test value 3 ), agreement (test-value 4) or strong agreement (test value 5) and whether the statistical differences are significant. The t-test compared two averages (means) and indicates if they are different from each other. By comparing the hypothesised value (2, disagreement) with the calculated values (1-5), detecting the students' views towards the relationship between teaching novels and writing skills is possible. The t-test also indicates how significant the differences are. In other words, the test shows if those differences could have occurred by chance.

\subsection{Validity and reliability}

To ensure the validity of the tool, the author structured the questionnaire according to linguists' classification of writing skills (Halliday and Hasan, 2014; Kellogg, 2008; Kroll, 1997). Furthermore, the questionnaire was refereed by two experts to validate the design of the questionnaire. Their comments are considered in the study. They recommended deleting some items of the questionnaire because of their irrelevance. They recommended the addition of some sub-skills of writing skills at the paragraph and sentence levels.

Cronbach's alpha was used as a measure of internal consistency, that is, how closely related a set of items are as a group. The results of the test showed that the items of the questionnaire are consistent. The alpha coefficient for the 23 items is 0.977 , suggesting that the items have relatively high internal consistency. A reliability coefficient of 0.70 or higher is considered 'acceptable' in most social science research situations.

\section{Results}

The findings are structured according to the research questions. The first question was about the students' opinion on the necessity of teaching novels for improving the English majors' writing skills. The students' responses revealed that the students agreed about the necessity of teaching novels for improving their writing skills.

Given that 23 post-tests were conducted, a Bonferroni correction was used to adjust for Type 1 error. Accordingly, 35 was divided by 0.05 (i.e., $0.05 / 23=0.002$ ). In doing so, the mean of the students' responses $(\mathrm{M}=3.53, \mathrm{p}<0.001, \mathrm{~N}=30)$ which is approximated to a value of 4 , meaning that the students agreed about necessity of the teaching novels for improving the students' writing skills (Table 1 ).

Table (1) One-Sample Test

\begin{tabular}{|c|c|c|c|c|c|c|c|}
\hline \multicolumn{8}{|c|}{ Test value-2 } \\
\hline Item & $M$ & SD & $\mathrm{N}$ & & $95 \% \mathrm{Cl}$ & $\mathrm{Df}$ & Sig \\
\hline & & & & Lower & Upper & & \\
\hline $\begin{array}{l}\text { 1. Study of novels is } \\
\text { necessary for improving }\end{array}$ & 3.53 & 1.306 & 30 & 1.05 & 2.02 & 29 & 0.000 \\
\hline
\end{tabular}




the writing skills of
students majoring in
English.

1. Study of novels is necessary for improving the writing skills of students majoring in English. $\quad 3.53$ $\begin{array}{llll}1.306 & 30 & 1.052 .0229 & 0.000\end{array}$

Table (1) shows the students' responses were statistically significant at the 0.01 significance level, from the predefined value of $2(\mathrm{M}=3.53, \mathrm{SD}=1.306, \mathrm{~N}=30,95 \% \mathrm{Cl})$ on mean difference $=1.05$ to $2.02, \mathrm{t}$ $\left.=6.430, \mathrm{df}_{\mathrm{f}}=29, \mathrm{p}<.001\right)$. Results showed that the observed value has a higher mean than predefined value (option of disagreement), meaning that the students' responses were centred around the option of agreement.

The second question was on the relationship between studying novels and writing skills. Given that 23 post-tests were conducted, a Bonferroni correction was used to adjust for Type 1 error. Accordingly, 35 was divided by 0.05 (i.e., $0.05 / 23=0.002$ ). The students' opinions were positive, which was manifested in the mean score of their responses $(M=4.20, S D=0.997, p<0.001, N=30)$. Results showed that the observed value has a higher mean than a predefined value (option of disagreement), meaning that the students' responses are centred on the value of agreement, as seen in Table (2).

Table (2) One-Sample Test

\begin{tabular}{|c|c|c|c|c|c|c|c|}
\hline \multicolumn{8}{|c|}{ Test value-2 } \\
\hline Item & $\mathrm{M}$ & SD & $\mathrm{N}$ & & $95 \% \mathrm{Cl}$ & $\mathrm{Df}$ & Sig \\
\hline & & & & Lower & Upper & & \\
\hline $\begin{array}{l}\text { 1. A relationship occurs } \\
\text { between teaching novel } \\
\text { and writing skills }\end{array}$ & 4.20 & 0.997 & 30 & 1.83 & 2.57 & 29 & 0.000 \\
\hline
\end{tabular}

The last scale question consisted of two parts: sentence and paragraph levels, and it addressed the areas in which novel teaching enhances writing skills at these levels. Generally, the students' answers revealed their agreement on the enhancement of teaching novels for the development of writing skills at the sentence and paragraph levels. Details are in the following sections.

\subsection{Writing skills at a sentence level}

The analysis revealed students' agreement on the role of teaching novels in developing writing skills at a sentence level, which are manifested in the mean scores of the students' responses, which range in all the items of the first section from 3.73-4.00, $\mathrm{P} \leq 0.001$. Given that 23 post-tests were conducted, a Bonferroni correction was used to adjust for Type 1 error. Accordingly, 35 was divided by 0.05 (i.e., $0.05 / 23=0.002$ ). The analysis revealed that students' responses are centred on the value of agreement, as seen in Table (3).

Table (3) One-Sample Test

\begin{tabular}{llllll}
\hline items & \multicolumn{2}{l}{ Test Value $=2$} \\
& $M$ & SD & df & $\begin{array}{l}\text { Sig. } \\
\text { tailed })\end{array}$ & (2- $95 \%$ IC
\end{tabular}




\footnotetext{
1. Novel teaching develops students' 4.00 structure of sentences.

2. Novel teaching provides students 3.73 with lexical chunks such as formulaic language (such as idioms and proverbs)
}

3. Novel teaching improves students' 4.20 vocabulary.

4. Novel teaching improves students' 4.13 ability to use vocabulary correctly in meaningful sentences.

5. Novel teaching Improves students' 3.77 use of tense.

6. Novel teaching improves students' 3.87 use of word order.

7. Novel teaching improves students' 3.77 use of articles.

8. Novel teaching improves students' 3.77 use of prepositions.

1.174

1.12

2

29

0.000

1.78

1.008

29

0.000

1.76

.97

$29 \quad 0.000$

1.40

1.042

29

0.000

1.48

2.26

$1.357 \quad 29 \quad 0.000$

1.26

2.27

1.165

29

0.000

1.767

1.33

\subsection{Writing skills at a paragraph level}

In the second section of the third question, the analysis revealed students' agreement on the role of teaching novels in developing writing skills at a paragraph level. Given that 23 post-tests were conducted, a Bonferroni correction was used to adjust for Type 1 error. Accordingly, 35 was divided by 0.05 (i.e., $0.05 / 23=0.002$ ). Such results were manifested in the mean scores of the most items of the questionnaire in the range of 3.73-4.20, $\mathrm{P}<0.001$. Three items did not show students' agreement on the role of novel teaching in developing students' writing skills, namely, use of reference $N(M=3.30, S D=1.264, N=30)$, ellipsis ( $N=3.47, S D, 0.860, N=30$ ) and organising a paragraph ( $M=3.27, S D, 0.868, N=30)$, as seen in Table (4). One of the lowest mean scores was students' agreement on the role of novels in developing students' logic in writing $(M=3.50, S D=0.974, N=30)$. These items four items showed the students' responses between the neutral value (Value-3) and agreement value (Value-4), as seen in Table (4).

Table (4) One-Sample Test

\begin{tabular}{|c|c|c|c|c|c|c|c|}
\hline \multirow[t]{3}{*}{ Items } & & \multicolumn{6}{|c|}{ Test Value $=0$} \\
\hline & & \multirow[t]{2}{*}{$M$} & \multirow[t]{2}{*}{ SD } & \multirow[t]{2}{*}{$d f$} & \multirow{2}{*}{$\begin{array}{l}\text { Sig. (two- } \\
\text { tailed) }\end{array}$} & \multicolumn{2}{|l|}{$95 \%$ IC } \\
\hline & & & & & & Lower & Upper \\
\hline & $\begin{array}{l}\text { Novels expose students to authentic } \\
\text { language. }\end{array}$ & 3.83 & 1.177 & 29 & 0.000 & 3.39 & 4.27 \\
\hline
\end{tabular}


2. Novels expose students to different 4.03 types of paragraphs such as narrative and descriptive.

Novels show students coherence.

4. Novels expose students to the culture 4.03 of the native speakers.

5. Novels provide students with a good 4.20 model for the use of conjunctions.

6. Novels provide students with a good 3.30 model for the use of reference.

7. Novels provide students with a good 3.47 model for the use of the ellipsis.

8. Through writing about novels, students 4.10 learn how to draft.

9. Through writing about novels such as by 4.27 using themes, students learn how to think.

10. Through writing about novels such as by 3.27 using themes, students learn how to organise a paragraph.

11. Novel teaching shows students how to 3.70 edit paragraphs.

12. Novel teaching shows students how to 3.70 quote.

13. Novel teaching shows aspects of logic in 3.50 writing.

\author{
0.890
}

29

0.000

3.70

4.37

0.850

29

0.000

3.65

4.28

1.377

29

0.000

3.52

1.186

29

0.000

3.76

4.64

$\begin{array}{lllll}1.264 & 29 & 0.000 & 2.83 & 3.77\end{array}$

29

0.000

3.15

3.79

0.923

29

0.000

3.76

4.44

0.980

29

0.000

3.90

4.63

0.868

29

0.000

2.94

1.442

29

0.000

3.16

4.24

1.264

29

0.000

3.23

4.17

$0.974 \quad 29 \quad 0.000$

3.14

3.86

\section{Discussion}

An analysis of the students' responses revealed the students' awareness of the positive relationship between teaching novel and writing skills. Responses revealed that the students support the role of novel teaching in developing their writing skills at the sentence and paragraph levels. Specifically, the major findings revealed by the study were as follows.

1. The students' responses were centred on the value of agreement in all the items of the survey. Only four items were between the value of agreement and neutralism. The value of strong agreement did not occur in all the items of the survey.

2. The students had positive attitudes towards the role of the novel in enhancing writing skills.

3. Teaching novels is necessary for the students of the Department of English.

4. The students supported the role of teaching novels in developing writing skills at a sentence level, namely, 

a) development of sentence structure
b) the students' learning of lexical chunks
c) improvement of the students' vocabulary
d) the students' ability to use vocabulary correctly in meaningful sentences
e) students' use of tense
f) adequate use of the right word order
g) adequate use of articles
h) adequate use of prepositions

5. The students' responses showed they support the role of teaching novels in developing writing skills at a paragraph level, namely,

a. exposing the students to authentic language

b. exposing students to different types of paragraphs such as narrative and descriptive

c. developing coherence

d. exposing students to the culture of native speakers

e. providing students with a good model for the use of conjunctions

h. assisting students in the processes of drafting and thinking.

i. the students' responses were between neutral and agreement on the role of teaching novels in developing use of reference $N(M=3.30, S D=1.264, N=30)$, ellipsis $(N=3.47, S D, 0.860, N=30)$, organising a paragraph $(M=3.27, S D, 0.868, N=30)$ and logic $(M=3.50, S D=0.974, N=30)$.

The analysis revealed that none of the survey items received strong agreement. Most of the items received value of agreement. This interesting finding may reveal that the English language program and teachers of writing and novels did not establish a strong relationship between teaching novels and writing skills in terms of the courses and methods of teaching.

Securitising results showed the students' positive attitude towards teaching novels in the Department of English. Teachers of writing and novels need to fully consider students' responses to the items on the areas that teaching novels develops writing skills at the sentence and paragraph levels.

As for the sentence level, the students agreed that teaching novels develops their structure of sentences, lexical chunks, vocabulary, words use, correct order, articles and preposition use. Comparing these findings of this study with those of previous studies revealed that the findings of this study are specific, whereas the findings of previous studies were general. Rietdijk et al. (2017), Bloemert et al. (2019), Sargsyan and Sivasubramaniam (2013), Oda and Khaz'all (2009), Iman (2017), Paesani (2005), Erkaya (2003), Spack (1985), Hurst (1995), Collie and Slater (1991), Davies (1985) and Obediat (1997) found that literature in general, as well as short stories and novels, have a positive effect on the development of the students' learning of English. They also found that students have positive attitudes towards teaching literature in developing their language, namely, language skills. Providing students with the natural input in which they discover the rules assists students in mastering language skills at sentence levels. Oda and Khazall (2009) and Paesani (2005) found that teaching novels develops sub-writing skills such as spelling, handwriting, grammar and punctuation. Parkinson and Reid Thomas (2000) and Helton et al. (1998) argue that 'teaching novels stimulates the students' imagination, develops oral and written 
language skills, serves as a springboard for a multitude of holistic learning and critical thinking activities beginning with basic comprehension and writing'.

As regards the relationship of a novel with the development of writing skills at a paragraph level, the students agreed on the novel's development of writing skills at a paragraph level in terms of exposing students to authentic language, different types of paragraphs (narrative and descriptive), aspects of coherence, exposing students to the culture of native speakers, use of conjunctions, drafting and thinking. Many applied linguists and practitioners emphasise the important role of literary texts in improving the students' language skills in general and writing skills due to its comprehensible input that covers different styles of writing and authentic materials, interest, universality and variety (i.e., Bloemert et al. 2019; Rietdijk et al., 2017; Sargsyan and Sivasubramaniam, 2013; İnan, \& Yüksel, 2013; Belcher \& Hirvela, 2000; Brumfit, 1983; Brumfit \& Carter, 1986 and Carter, 1982).

The students' responses were between neutral and agreement on the role of teaching novels in developing the use of reference, ellipsis, organising a paragraph and logic. These results might be ascribed to the nature of teaching novels. The teacher may not expose the use of reference, organising a paragraph, ellipsis and logical presentation in teaching the students to comment or write about novels.

\section{Conclusion}

The study explored students' attitudes towards the role of the novel in enhancing writing skills. Investigating the students' views on certain courses and methods of teaching is an important issue that needs to be considered in language teaching and learning because it reflects the nature of teaching and its weakness and strengths. On the basis of the recognition of the teaching weakness' and strengths, teachers, syllabus designers should make necessary changes into the contents of courses and methods of teaching. The students' awareness of the role of the novel in developing writing skills needs to be considered by principals of English programs in terms of the making the courses of the program directed to developing students' language proficiency. Teaching novels should be incorporated in the EFL program, considering the students' linguistics level, age and interest. Teaching novels should be of dual purpose: to expose students to literary works and develop students' language skills. Furthermore, principals of EFL programs should consider the links between various courses in the curriculum development of the EFL program so that they all contribute to the development of students' language skills.

The study is descriptive. Thus, the study cannot determine a correlation or a causal effect between teaching novels and writing skills. Therefore, experimental and correlational studies are needed to investigate how the students' writing skills are developed through teaching novels to unfold whether teaching novels positively affects writing skills. Surveying students' perspective is insufficient. The sample of the study is small, so a large sample is needed to ensure the generalisability of results. Surveys that investigate both instructors of writing and students about the relationship between teaching novels and writing skills are needed. These surveys are expected to provide a complete image of teachers' and students' views of the development of writing skills through novels.

\section{Recommendations}

The main aim of the study was a pedagogical one, meaning that its findings are primarily intended to benefit teachers of novels and writing courses by effectively using them in the teaching situation of the English language. Furthermore, investigating the students' awareness of the role of novels in enhancing writing skills reflects learner-based perspectives in which students are at the centre of the learning process. The findings of the study revealed the students' attitudes towards teaching novels, possibly reflecting the shortcomings or strengths of teaching English in the process of designing syllabuses, writing materials and teaching inside the class. 
Most sections of the survey received the fourth value (agreement). None of the items of the survey received strong agreement, disagreement or strong disagreement. Drawing on this finding, teachers of novels should link between the activities of teaching novels and writing skills. Teachers of novels should not focus only on the events and characters of the novels but on the areas of association between teaching novels and writing skills so that students could benefit from teaching novels in developing writing skills. Teachers should make students aware of the relationship between novel teaching and writing skills through using the activities of the novels in developing students' writing skills (Collie \& Slater; 1991; Davies, 1985; Obediat, 1997; Helton et al. 1998; Oda \& Khazall, 2009). Similarly, instructors of the novel should use the potential of novels in developing students' writing skills. Teachers should use students' positive perspective of the relationship between teaching novels and writing skills by integrating writing skills in the activities and exercises of teaching novels. Instructors of novels also should provide students' authentic material in which students develop their writing skills implicitly and explicitly. Finally, syllabus and curriculum developers of English language programs develop links between language skills and literature in terms of selection of literary genres and courses and the appropriateness of the literary genre to the linguistic level of the students and their interests. Rietdijk et al. (2017) found that the comprehensive writing program had a beneficial effect on students' writing performance and the extent to which teachers taught writing strategies.

The classification of writing skills (at the paragraph and sentence levels) provided by the study should be considered by teachers of writing and novels by reflecting this classification in the contents of writing course and methods of teaching. Integrating novel teaching in the syllabus of undergraduate provides a sound methodology for developing language skills generally and teaching writing skills in specific. To effectively use teaching novels, the selection of novels for teaching in undergraduate programs should be based on analysis of the students' needs, writing skills to be covered and the language of the novels in terms of its appropriateness to the level of the students. Furthermore, a clear methodology should account for improving writing skills either at sentence or paragraph levels.

\section{References}

Akyel, A. (1990). Literature in the EFL class: A study of goal-achievement incongruence. ELT Journal, 44(3), $174-180$. doi: 10.1093/elt/44.3.174

Atasoy, S. (2013). Effect of writing-to-learn strategy on undergraduates' conceptual understanding of electrostatics. The Asia-Pacific Education Researcher, (22), 593-602. http://dx.doi.org/10.1007/s40299-013-0062-4.

Belcher, D. \& Hirvela, A. (2000). Literature and L2 composition: Revisiting the debate. Journal of Second Language Writing, 9(1), 21-39.

Bishop, W. (1995). The literary text and the writing classroom. Journal of Advanced Composition, 15, 435-454.

Bloemert, J. Paran, A., Jansen, E. \& Grift, W. (2019). Students' perspective on the benefits of EFL literature education, The Language Learning Journal, 47(3), 371-384.

Bretz, M. L. (1990). Reaction: Literature and communicative competence: A springboard for the development of critical thinking and aesthetic appreciation. Foreign Language Annals, 23(4), PP. 335-338.

Brumfit, C. \& Carter, R. (1986). Literature and language teaching. Oxford: Oxford University Press.

Brumfit, C. J. (Ed.). (1983). Teaching literature overseas: Language-based approaches.

Collie, J., \& Slater, S. (1991). Literature in the language classroom (5th ed.). Glasgow: Cambridge University Press.

Cook, G. (1994). Discourse \& literature: The interplay of form and mind. Oxford: Oxford University Press. 
Crook, G., Schmidt, R. (1991). Motivation: Reopening the research agenda. Language Learning, 41 (4), 469-512.

de Winter, J.\& D. Dodou (2010). Five-Point Likert items: $t$ test versus Mann-Whitney-Wilcoxon. Practical Assessment, Research \& Evaluation, 15(11), 1-16.

Erkaya, O. (2005). Benefits of using short stories in the elf context. benefits of using short stories in the elf context. Asian EFL Journal, (8), 1-13.

Gajdusek, L. (1988). Toward wider use of literature in ESL: Why \& how. TESOL Quarterly, 22(2), 227-257.

Halliday, M. \& Hasan, R. (2014). Cohesion in English. Hoboken: Taylor \& Francis.

Harmer, J. (2004). How to teach writing. England: Pearson Education Limited.

Harpe, S. (2015). How to analyze Likert \& other rating scale data. Currents in Pharmacy Teaching \& Learning, 7(6), pp.836-850.

Hedge, T. (1988) Writing. Oxford: Oxford University Press.

Helton, C., Asamani, J. \& Thomas. D. (1998). A Novel approach to the teaching of reading. Tennessee State: Tennessee State University

Hirvela, A. (1998). Review of the book Myra Shulman's journeys through literature. English for Specific Purposes, 17(3), 237-326.

Hull, G., \& Rose, M. (1990). This wooden shack place: The logic of an unconventional

reading. College Composition Communication, (41), 287-298.

Hurst, N. (1990). The literature option at CPE. Modern English Teachers, 17, (1), 68-75.

Iman, J. (2017). A quasi-experimental study on using short stories: statistical \& inferential analyses on the nonEnglish major university students' speaking \& writing achievements. International Journal of Languages' Education \& Teaching. 5(1), 421-433.

Innan, B. \& Yüksel, D. (2013). Literature and language teaching: A coursebook. Istanbul: Pegem Akademi.

Kellogg, R.T. (2008). Training writing skills: A cognitive-developmental perspective. Journal of writing research, 1(1), 1-26

Kelly, R. K., \& Krishnan, L. (1995). Fiction talk in the ESP classroom. English for Specific Purposes, 14 (1), 77-86

Klein, P. Boscolo, P. (2016). Trends in research on writing as a learning activity. Journal of Writing Research, 7(3), 311- 350. doi: 10.17239/jowr-2016.07.03.01

Klein, P., Piacente-Cimini, S. \& Williams, L. (2007). The role of writing in learning from analogies. Learning \& Instruction, (17), 595-611.

Kramsch, C. (1993). Context and culture in language teaching. Oxford, UK: Oxford

Krashen, S. (1998). Comprehensible output? System, 26(2), 175-182.

Kroll, B (1997). Second language writing (Cambridge Applied Linguistics): Research insights for the classroom. Cambridge: Cambridge University Press.

Lazar, G. (1993). Literature and language teaching. Cambridge: Cambridge University Press.

Liaw, M. (2001). Exploring literary responses in an EFL classroom. Foreign Language Annals, 34(1), 35-44. doi: 10.1111/j.1944-9720.2001.tb02800.x

Lindemann, E. (1993). Freshman composition: No place for literature. College English. (55), 311-316.

Martin, A., \& Laurie, I. (1993). Student Views About the Contribution of Literary and Cultural Content to Language Learning at Intermediate Level. Foreign Language Annals, 26(2), 188-207. doi: 10.1111/j.1944-9720.1993.tb01166.x. 
McCutchen, D., Teske, P., \& Bankston, C. (2008). Writing and cognition: Implications of the cognitive architecture for learning to write and writing to learn. In C. Bazerman (Ed.), H\&book of research on writing: History, society, school, individual, text (pp. 451-470). New York, NY: Taylor \& Francis Group.

McKay, S. (1982). Literature in the ESL classroom. TESOL Quarterly, 16 (4), 529-526.

McKay, S., \& Petitt, D. (1984). At the door: Selected literature for ESL students. Englewood Cliffs, NJ: Prentice-Hall.

Mohsen, M., \& Qassem, M. (2020). Analyses of L2 learners' text writing strategy: Process-oriented perspective. Journal of Psycholinguistic Research, 49(3), 435-451. doi: 10.1007/s10936-020-09693-9

Obediate, M. (1997). Language Vs. literature in English Departments in the Arab world. English Teaching Forum, 35(1), 19-34.

Oda, A. \& Khazall, J. (2009). The Role of teaching the English novel in developing language skills. Journal of Basrah Researches (Humanities Series), 34(1), 55-73.

Omar, I \& Baker, D. (1992). Problems in teaching English literature in Arab Universities. Mu'tah Journal for Research \& Studies, 7(4), 9-18.

Paesani, K. (2005). Literary texts \& grammar instruction: Revisiting the inductive presentation. Foreign Language Annals, 38(1), 15-23.

Paran, A. (2008). The role of literature in instructed foreign language learning and teaching: An evidence-based survey. Language Teaching, 41(4), 465-496. doi: 10.1017/s026144480800520x

Pardede, P. (2011). Using short stories to teach language skills. Journal of English teaching 1(1), 1-27.

Raimes, A. (1985). What unskilled ESL students do as they write: A classroom study of composing. TESOL Quarterly, 19(2),229-258.

Rietdijk, S., Janssen, T., Van Weijen, D., Van den Bergh, H., \& Rijlaarsdam, G. (2017). Improving writing in primary schools through a comprehensive writing program. Journal of Writing Research, 9(2), 173-225. doi: 10.17239/jowr2017.09.02.04.

Robson, A. E. (1989). The use of literature in ESL and culture-learning courses in US

colleges. TESOL Newsletter 23, 25-27.

Sargsyan, A. \& Sivasubramaniam, S. (2013). Using literature to promote language learning: issues and insights for implementation in Armenian settings. The Asian EFL Journal Quarterly, 15(4), 40-82.

Savvidou, C. (2004). An integrated approach to the teaching of literature in the EFL classroom. The Internet TESL Journal, .5 (1), 4-19.

Spack, R. 1985. Literature, reading, writing, and ESL: Bridging the gaps", TESOL Quarterly. 19(4), 703-721.

Tudor, I. (1993). Teacher roles in the learner-centred classroom. ELT Journal, 47(1), 22-31.

University Press.

Williams, J. (2003). Preparing to teach writing. Mahwah.: Lawrence Erlbaum Associates.

Yildiz, A. (2012). Prospective teachers' comprehension levels of special relativity theory \& the effect of writing for learning on achievement. Australian Journal of Teacher Education, 37, 15- 28. http://dx.doi.org/10.14221/ajte.2012v37n12.1

Zacharias, N. \& Manara, C. (2011). Bringing literature and linguistics into EFL classrooms. Newcastle upon Tyne: Cambridge Scholars Publishin 
Appendix

- $\quad$ Name (optional):

- Level:

- $\quad$ Age :

- $\quad$ Gender:

Mark with ' $X$ ' the extent to which you agree with the following statements.

N Statements Strongly disagree disagree Neutral agree Strongly agree

1. Study of novels is necessary for improving the writing skills of the students majoring in English.

2. There is a relationship between writing skills and teaching novels

Mark with ' $X$ ' the extent to which you agree with the following statements:

(a) Writing skills on the level of a sentence

Statements Strongly disagree disagree Neutral agree Strongly agree

1. Novel develops students' structure of sentences by exposing them to simple, compound and complex sentences.

2. Novel provides students with lexical chunks such as formulaic language(idioms, proverbs, etc. )

3. It improves students' vocabulary.

4. It improves students' ability to use vocabulary correctly in meaningful sentences.

5. It improves students' use of tense.

6. It improves students' use of word order.

7. It improves students

use of prepositions.

8. It improves students' use of articles. 
B. Writing skills on the level of a paragraph

statements Strongly disagree disagree Neutral agree Strongly agree

1. Novel exposes students to authentic language.

2. Novel exposes students to different types of paragraphs(narrative, descriptive etc.)

3. Novel shows students' aspects of coherence.

4. It exposes students to the culture of the native speakers.

5. It provides students with a good model for the use of conjunctions.

6. It provides students with a good model for the use of reference.

7. It provides students with a good model for the use of ellipsis.

8. Through writing about the novel, students learn how to think.

9. Through writing about the novel, students learn how to draft

10. Through writing about the novel, students learn how to organize a paragraph.

11. Novel teaching shows students how to edit paragraph

12. Novel shows students how to quote.

13. It shows students aspects of logic in writing 